\title{
The Effectiveness of Law Enforcement against Violations of the Law on Prohibition of Monopolistic Practices and Unfair Business Competition
}

\author{
Raden Murjiyanto \\ Faculty of Law, Janabadra University, Yogyakarta, Indonesia \\ Email: rmurjiya@yahoo.com
}

\begin{abstract}
In order to create an economic condition with good business governance, on March 5, 1999 promulgated Law number 5 of 1999 concerning The Prohibition of Monopolistic Practices and Unfair Business Competition, which is legalized effectively on March 5, 2000. It has also been followed by the establishment of an institution which is authorized to conduct an investigation and to decide cases by imposing sanctions on business actors who violate the Law, which is called the Business Competition Supervisory Commission (BCSC) or in Indonesia is called as Komisi Pengawas Persaingan Usaha (KPPU). However, the implementation is still not effective until now because there are still some monopolistic practices and unfair business competitions conducted by business actors, but some BCSC's decisions are cancelled by the Court. Besides, the Law itself provides a space for the occurrence of monopolistic practices, and the law enforcement agencies cannot get the business actors who do the monopolistic practices and unfair business competition. Based on those several problems, the research was conducted a research on Law Enforcement against Violations of the law by the BCSC. The first problem from this research is why some BCSC's decisions were cancelled by the Court? The second problem is how to enforce the law against violations of the monopoly law effectively? The research is using normative approach method, by reviewing the applicable laws and regulations, and also some documents of Decision on the violation case of the law.
\end{abstract}

Keywords - Law enforcement; monopoly; competition

\section{INTRODUCTION}

As mandated in the Article 33 (4) of the 1945 Constitution it is said that the national economy is organized based on economic democracy with the principles of togetherness, fair efficiency, sustainability, environmental insight, independence, and by maintaining a balance of national economic improvement and unity. Based on the Constitution in field of business, the state is given the authority to monopolize, by controlling the business fields that fulfill the livelihood of the citizen, but it must be done for the prosperity of the society. Based on Article 33 (2) and (3) of the 1945 Constitution, some products that are important for the state and which affect the livelihood of the people are controlled by the state, while the earth, water, and natural resources contained therein are controlled by the state and used for the greatest prosperity of the citizen. Those certain business fields are electricity, railways, oil, gas, and drinking water.

Accordance with the mandate of the 1945 Constitution, the role and responsibility of the State in the management of oil and gas in the border of Indonesia should be oriented to the prosperity of the people of Indonesia (Zulkarnain, 2018: 111). The economic crisis in Indonesia in 1997 which ended with the fall of "new order" power in 1998 occurred due to the failure of state-run economic development, so the state's goal to achieve independence for prosperity and welfare of the citizen could not be achieved, where all the prices of the needs were increased, the currency was weakened and many companies were bankrupt including the banking sector. It was also influenced by some business activities that were not based on the professional ability, but only relied on proximity to the ruler which resulted the company was unable to deal with the crisis that occurred globally, where at that time, the power of the "New Order" regime was too strong in the social, politic, economic and legal fields (Maulana, 2000: 228). That conditions forced Indonesia to inevitably have to accept the intervention of an International Monetary Fund (IMF) institution to help Indonesia escape from the crisis with the provision of creating the Law on Business Competition, including Indonesia must stop a program of national car, which in Indonesia was called as mobnas (mobil nasional), which was considered incompatible to the principle in fair business competition. The current business development of globalization has promised new opportunities and challenges for companies in Indonesia (Yuhelson Yuhelson, 2017: 674).

Entering the reform era, in order to overcome the economic conditions to create a good business governance, on March 5, 1999 promulgated Law number 5 of 1999 on Prohibition of Monopolistic Practices and Unfair Business 
Competition, which is valid effectively from March 5, 2000. Although the establishment of that Law is considered a bit late, but it may still be better than not having any law at all (Maulana, 2000: 229).

Law Number 5 Year 1999 on Prohibition of Monopolistic Practices and Unfair Business Competition Article 53 states that the establishment of this law is valid in 1 (one) year from the date of promulgation. It can be said that this legal product is the key for Indonesia to escape the crisis situation at that time. However, the monopolistic practices and unfair business competition still often occurs along with the development of society's need for goods and services. In other words, oligopoly, cartel and other anti-monopoly actions are still ongoing.

In order to enforce the law, it has also been followed by the establishment of an institution authorized to conduct an investigation and to decide cases of violation of the Law, which is called as the Business Competition Supervisory Commission or BCSC as a mandate of the Prohibition of Monopolistic Practices and Unfair Business Competition Law.

Monopolistic practices and unfair business competition which still happen in Indonesia may be a sign of weakness and ineffectiveness of the law enforcement against violation of monopoly and business competition law. Several cases have been handled by the Business Competition Supervisory Commission (BCSC) and have been set by the imposition of a fine, but unfortunately some BCSC's verdicts are cancelled by the Court, as in the case of Carrefour, cooking oil cartel, and others. Not only because of the Law on Prohibition of Monopolistic Practices and Unfair Business Competition which give a gap for the occurrence of monopolistic practices, but also it is because the law enforcement agencies cannot get the business actors who do it. Monopolistic practices and business competition is clearly detrimental to consumers, the citizen of Indonesia. Based on some of those issues, it is interesting to do research on: The Effectiveness of Law Enforcement against Violations of the Law on Prohibition of Monopolistic Practices and Unfair Business Competition.

This research is based on some problems, those are: why some BCSC's verdicts are cancelled by the Court? The second problem is how to enforce the law against violations of the monopoly law effectively? The method that is used is normative research method, by reviewing some documents, judicial verdicts and regulations.

\section{RESEARCH METHOD}

The method of this research is normative research method, by reviewing several documents, judicial decisions and applicable regulations. The Legal Sources used are:

a. Law Number 5 of 1999 on Prohibition of Monopolistic

Practices and Unfair Business Competition

b. Regulation of the Business Competition Supervisory Commission Number 1 of 2010 on Procedures for Case Handling

c. Supreme Court Regulation Number 3 of 2005 on Procedures for Submitting Legal Remedies for
Objection to BCSC's Decisions

BCSC's decision documents that were cancelled by District Court are:

1. BCSC's Decision Number 09/BCSC-L/ 2009 (Carrefour)

2. BCSC's Decision Number 24/BCSC-I/2009 (Edible Oil Cartel)

3. BCSC's decision Number 02/BCSC-I/2016 (Chicken Meat Cartel)

4. BCSC's decision Number 5/BCSC-I/2014 and PN Decree Number 615/Pdt.Sus/BCSC/2014/PN.Jkt.Pst (BRI)

5. BCSC Decision Number 03/BCSC-L/2012 (E-KTP)

It was also done by depth analyzing in several regulations relating to the authority and procedures for the BCSC's decision making which eventually were cancelled by the District Court. Data and information obtained will be analyzed descriptively qualitative, so that conclusions can be drawn that can be scientifically justified.

\section{RESULTS AND DISCUSSION}

A. The Effectiveness of Law Enforcement against Violation of Monopoly and Unfair Business Competition Law by Business Competition Supervisory Commission (BCSC)

Basically, law enforcement is a series of activities conducted by authorized law enforcement officers that handle the violation of certain regulations, by doing the process of inspection until the implementation of the verdict. Law enforcement, as simply formulated by Rahardjo (1983: 24), is a process for realizing the legal desires to come true. The legal desires are those thoughts of the legislatures formulated in these laws. Thus, in turn, the law enforcement process culminates in its implementation by law enforcement officers. The success or failure of law enforcement officers in carrying out their duties has actually started since the execution of rule of law was made.

In order to enforce the law of Prohibition of Monopoly Practices and Unfair Business Competition, it was created the Business Competition Supervisory Commission (BCSC) as mandated by the Law. Based on the constitutional system, BCSC is a complementary state institution or state auxiliary organ (Kagramanto, 2207: 2). BCSC has an authority based on Law to enforce law from the violation of monopoly and business competition law. State institutions which established outside of the constitution are also often called as quasi-independent state institutions. The role of a quasi-independent state institution becomes important as a responsive effort for countries transitioning from authoritarianism to democracy (Asshidiqie, 2009: 312). According to Law number 5 of 1999 on Prohibition of Monopolistic Practices and Unfair Business Competition Article 1 (18), Business Competition Supervisory Commission is a commission established to supervise business actors in running their business activities in order not to do monopoly and / or unfair business competition. This commission is independent regardless of the influence of 
any parties including the influence of governmental power. BCSC as one of the law enforcement agencies has a complex task in overseeing unfair business competition practices by business actors. This happens because there are increasingly massive business activities in various fields with strategic modifications to win the competition among competitors (Mantili, et al., 2016: 117). Therefore, it does not close the possibility of business actors doing things that are prohibited and can harm other parties. In that case, the role of BCSC is very necessary in enforcing the law against the violation of the Law on Prohibition of Monopolistic Practices and Unfair Business Competition.

The establishment of an institution for handling the violations of monopolistic practice and unfair competition laws is intended to create effective and efficient settlement of cases, considering that the cases handling from the general court is through several complicated stages and considered that there is a lot of judicial mafia. The judiciary in Indonesia, however, is regarded as one of the most corrupt institutions which many businesses avoid in cases of dispute settlement. The eradication of "judicial mafia" (mafia hukum) still constitutes an urgent task for the government (Fukuoka, 2012: 9).

In order to do law enforcement tasks, BCSC has issued Regulation of the Business Competition Supervisory Commission Number 1 of 2010 on the Case Handling Procedure, which can be written as BCSC's Regulation of 2010. This regulation is issued in lieu of previous regulation namely Commission's Regulation Number 01 of 2006 on Case Handling Procedure in BCSC. Based on prohibition of monopolistic practices and unfair business competition and BCSC Regulation, case handling is conducted by BCSC based on: a. Report from Informer b. Report from Informer with a request for compensation or c. The initiative of the Commission, with the following stages:

1. Case handling based on report from informer which consists of the following stages: a. Report, b. Clarification, c. Investigation, d. Filing, e. Assembly of Commission Council and $f$. Commission's Verdict.

2. Case handling based on Report from informer with a request for compensation consists of the following stages: a. Report, b. Clarification, c. Assembly of Commission Council and $d$. Commission's Verdict.

3. Case handling based on Commission's initiative consists of the following stages: a. Review, b. Research, c. Supervision of Business Actor, d. Investigations, e. Filing, f. Assembly of Commission Council; and g. Commission's Verdict.

In the event that the Commission conducts an examination on the basis of a report, it is determined that any person who knows that a violation of the Law has occurred or is reasonably suspected can report to the Commission, by making a letter of report addressed to the
Chairman of the Commission by using proper and correct Indonesian which consists of:

a. the identity of the Informer, Reported Party, and Witness;

b. explain clearly and wherever possible and thoroughly and accurately of the occurrence or allegation of violation of the Law;

c. evidence of alleged infringement;

d. a copy of the Informer identity; and

e. Signed Report.

The Informer who requires compensation, the also shall include the value and evidence of damages suffered. Those reports may be submitted through the Regional Representative Office of the Commission.

The Commission may also handle the cases based on data or information, in the absence of reports, of alleged violations of the Law, sourced at least from: a. Results of Study, b. News in the media, c. Results of Supervision, d. incomplete report, e. Results of the Commission's hearing, f. Findings in Examination; or g. other sources that can be accounted for. Based on the results of the review, the Commission shall follow up the Report on the Assessment Results to provide advice and consideration to the government and / or to proceed to the stage of Investigation. In case there is a strong indication of violation and inspection required, the examination will be conducted through several stages: preliminary stage, follow-up examination until the Commission's verdict.

In relation to the Commission's verdicts, the Reported Party may submit an objection no later than 14 (fourteen) days after the receipt of the Commission's Verdict Letter and a copy of the Commission's verdict, which submitted in the District Court based on the place of the Reported Party. The objection of the District Court's verdict may be submitted Cassation to the Supreme Court.

If the Reported Party does not submit an objection on the stipulated time, the Reported Party shall implement the Commission's Verdict and submit its implementation report to the Commission no later than 30 (thirty) days after the expiration of the objection period. If the Commission considers that the Reported Party does not carry out a Commission's Verdict of at least 2 (two) cases, the Commission may submit the case to the Police of the Republic of Indonesia for criminal proceedings.

If the Reported Party does not implement the Commission's or the District Court's or the Supreme Court's verdict which has had permanent legal force, the Commission shall submit the Verdict to the District Court for the Stipulation of Execution.

The objection effort to the District Court of the Commission's verdict becomes a weakness in the law enforcement of the monopolistic practices and unfair business competition law. It is proven by several cases that have been decided by BCSC are cancelled by the District Court. BCSC's law enforcement efforts cannot be categorized as optimal efforts. Although there are so many incoming reports, around 400 reports, and BCSC handles many cases, but the case is still in tender case with a fine of one or two billion (Arifardhani, 2012: 10). 
Based on data which published in the Periodic Media of the Business Competition Supervisory Commission titled KOMPETISI edition number 32 Year 2012, it stated that during the year 2006-2011, BCSC has strengthened its position and role as a business competition supervisory institution. With the motto "Fair Competition Increases Citizen's Welfare", BCSC's contribution in economic growth is more real. Although the indicator of success of an institution is often seen in terms of quantity or number of cases handled, but for BCSC is also seen from the outcome. This means that there is an economic impact felt directly or indirectly by the community. In the five year in second period, BCSC has received reports of alleged violations against Law Number 5 Year 1999 as many as 1253 official reports.

Not only receiving reports from the public, BCSC also conducts supervision and research. The case that started from the research by BCSC and not from the report of the community is called as the initiative case. During this period of 2006 - 2011, BCSC has handled 205 cases which consist of 21 initiative cases and also 184 cases based on reports. From 205 cases, BCSC has reviewed and decided on 161 Verdicts and 39 Determination which consist of 140 Verdicts stating violations of Law Number 5 Year 1999 and 21 Verdicts stating no violations occurred. Meanwhile, from the 39 determinations, there were 28 determinations which un-indicated as violations of Law Number 5 Year 1999 and 11 determinations indicating behavior change. Reviewed from the substance of the violations which become the base of the examination and verdict making, $75 \%$ or 154 of 205 cases are related to the procurement tender of goods and services.

Based on the BCSC's verdicts, several business actors submitted an Objection Efforts to the District Court. Besides, dissatisfaction of the District Court's verdict, the reported business actor also submitted an appeal to the Supreme Court. The result percentage of the handling of Objections in the District Court as well as the handling of cassation in the Supreme Court can be seen in the pie chart as shown in Fig. 1:

\section{FIG.1 COMPARISON OF BCSC'S VERDICTS WHICH HAVE BEEN CANCELLED AND REINFORCED}

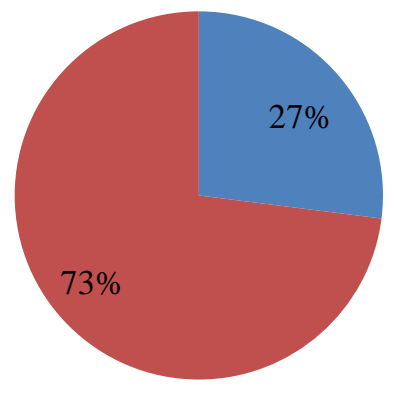

Reinforced by The Supreme Court

- Cancelled by The Supreme Court

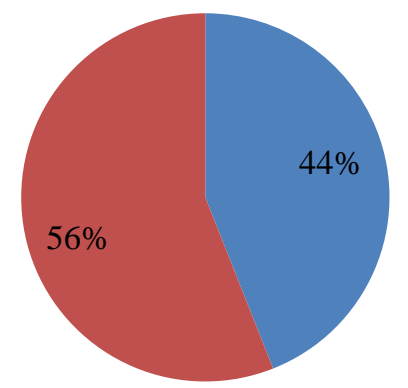

Cancelled by The District Court

Reinforced by

The District

Court

Source: BCSC's Report on 2011

Until 2011, the verdicts issued by BCSC were 86 with the objection to the District Court and 58 verdicts of the cassation to the Supreme Court. At the District Court level, $56 \%$ or 48 out of $86 \mathrm{BCSC}$ 's verdicts are reinforced and 38 cases are cancelled. At the Supreme Court level, there are 58 appeals toward the District Court's decision, and the result of $76 \%$ or 44 BCSC's verdicts is reinforced and the rest are cancelled by the Supreme Court.

Although it does not become the main objective, in ten (10) years, BCSC has imposed a fine of 949.542.844.090,00 rupiahs and compensation in the amount of $919.691 .129 .987,00$ rupiahs with a total of 1.869.233.974.077,00 rupiahs.

The Law Commission Member of the Republic of Indonesia House of Representatives, Gayus Lumbun, also sees that BCSC is still weak. "Many verdicts have been cancelled by the court, unlike the Indonesian National Arbitration Board whose verdict is irrevocable". Several cases of BCSC's verdict have been cancelled by the court for legal effort of objections, such as the case of acquisition of PT. Alfa Retailindo by Carrefour, Cooking Oil Cartel, Beef Cartel, and also E-KTP Tender Case.

Whereas in the BCSC's report of 2016, target and achievement of case handling as shown in the TABLE 1: TABLE I. ASSEMBLY COURT'S VERDICT LIST

\begin{tabular}{|l|l|l|l|}
\hline Activity & Target & Achievement & Information \\
\hline Report & 127 & 227 & \\
\hline Cases & 5 & 26 & \\
\hline Assembly Court's Verdicts & 22 & 24 & $\begin{array}{l}24 \text { Assembly } \\
\text { Courts and } \\
\text { (BCSC) } \\
\text { (BCSC) Verdicts }\end{array}$ \\
\hline PN-MA Level & & 17 & \\
\hline
\end{tabular}

Source: BCSC's Report Year 2016

Some BCSC's verdicts are still being submitted a review effort which extending the settlement of the case, besides there is a judicial review verdict which cancelled a previous verdict that has been implemented. This is possible considering the efforts of the judicial review do not delay the execution, so it is possible that the verdict which submitted a judicial review has been implemented.

The purpose law is for public order, and in its implementation must provide legal certainty and justice for interested parties. Between legal certainty and justice both are interconnected, which must be achieved in a balanced 
manner. The solution can be given by rules that fulfill an interest in sacrificing other interests, or making a compromise between conflicting interests. According to Gustav Radbruch, the law is formed at least with three considerations. Those are justice (gerechtigheit), legal certainty (rechtssicherheit) and expediency (zweckmassigheit). The existence of legal certainty is needed to achieve justice. The legal effort mechanism which is submitted to the District Court as the first level of justice, and the fact that there are several BCSC's decisions that are cancelled; do not provide legal certainty and justice, and it gives an illustration that BCSC's decision does not have strong legal force because it is easy cancelled by the court.

\section{B. Obstacles in Law Enforcement against Violations of the Law on Monopoly and Business Competition by the Business Competition Supervisory Commission (BCSC)}

Regulation of the Law on Prohibition of Monopolistic Practices and Unfair Business Competition aims to enable every business actor to participate and compete fairly in conducting his business activities. The government on one side wants to move the economy by encouraging developments in the business world, but on another side must create a regulation so that business activities are done correct and not endanger each other. However, sometimes the regulation is considered to be an obstacle for business actors. For the example, the imposition of sanction of fines in handling cases of violation of law is considered to disrupt the business climate and counterproductive. Currently, business competition fines are often a polemic among business actors who are found guilty by BCSC. The business actors often say that the imposition of fines is considered potentially disrupt the business and investment climate so it affects counterproductive on the national economy. As regulated in Article 47 (2), the imposition of fine is minimum 1.000.000.000,- rupiahs (one billion rupiahs) and maximum 25,000,000,000,- rupiahs (twenty five billion rupiahs).

From the BCSC's report, during 2016, BCSC has determined 22 out of 24 ongoing cases. From these 22 cases, BCSC successfully imposed a fine of 350.318.471.156 rupiahs, For example, from three cases handled by BCSC, case number 01 / BCSC / BCSC-L / 2016, number 02 / BCSC-L / 2016 and number 03 / BCSC-L / 2016, the total penalty imposed to the Reported Party amounted to 146.533 .523 .338 , - rupiahs.

On the other hand, fine sanctions also do not fully provide deterrent effect for business actors. The problem of imposition of fine which is often faced by BCSC is the perpetrator (reported) is not deterrent to do a similar act. It is happened because in business behavior, for example in a tender case, usually the business actor has more than one company. While the provisions of criminal sanctions which can be found in the prohibition of monopolistic practices and unfair business competition law provides an alternative of criminal sanctions choice between fine or confinement which is unbalanced, that is, as regulated in
Article 48 (1), criminal threat is minimum 25.000.000.000, - rupiahs (twenty five billion rupiah) and maximum 100,000,000,000, - rupiahs (one hundred billion rupiah), or a confinement of 6 (six) months. The choice of fines and confinement is unbalanced, which 6 months confinement is too low.

In terms of law enforcement process, BCSC's verdict is still considered weak, including the provision of a legal effort mechanism as objections to the District Court. As in the judicial process in general, the court examines and decides cases at the first level, in which case the legal objection to the BCSC's verdict through the district court as a court of first level is not appropriate because between the BCSC and the district court are the same institutions which examine and decide cases at the first level. In fact, many BCSC's verdicts are cancelled by the district court through an objection effort, and there are even BCSC's verdicts are submitted a lawsuit to civil service arbitration tribunal and cancelled. Several examples of BCSC's verdicts which were cancelled by the District Court through an objection effort are the acquisition of PT Alfa Retailindo by Carrefour, cooking oil cartel, Beef Cartel, the case of mortgage customers' insurance option at BRI, and E-KTP Tender Case. From some cases, the objections were submitted through the court, but were ultimately cancelled and declared not proven as a violation in spite of the different paradigms from court judges and BCSC commissioners (Mantili, et al., 2016: 120). Besides, in Law number 5 of 1999 does not stipulate the authority of BCSC to do Prejudgment Seizure (Conservatoir Beslag) on business assets, and BCSC does not have bailiffs as well as the courts, so that in execution of BCSC's verdict must go through a state court, because BCSC does not have the force power as the judiciary, police, and prosecutor (Mantili, et al., 2016: 119). This can be an obstacle to BCSC in conducting the inspection action or when its verdict must be carried out by force or execution.

In the implementation of its duties, BCSC still has obstacles that result BCSC has not been able to perform optimally. Those obstacles are although BCSC has the authority to request information from Government agencies, but until now, there has been no good cooperation between BCSC and government agencies. Therefore, BCSC often faces some difficulties in performing its duties due to the lack of supporting data. The other obstacle is even though BCSC has the authority to summon the business actors or witnesses, BCSC cannot force them. Besides, there is lack of information dissemination on the authority of BCSC in handling monopoly cases and unfair business competition to the public especially to business actors. This resulted the citizen has not been ready when having to deal with BCSC. Those obstacles should be the main focus of repairing the BCSC's role in achieving the aspired goal of realizing an efficient Indonesian economy with the creation of a conducive business climate, and ensuring legal certainty and striving for the community, especially business actors. Besides, the weaknesses of some BCSC's decisions which have been cancelled by the court through the objection to the District Court, the legal efforts of the 
business actor should not be objected to the district court, but to the High Court as well as the appeal submission in the case in general. This is also intended as a recognition and legal force to the BCSC institution which established and authorized as a dispute resolution institution based on the law.

\section{CONCLUSION}

Based on the analysis and discussion of the problem, it can be concluded that Law enforcement against Violations of Monopoly and Business Competition Law through BCSC is still not effective. This is proven to some BCSC's verdicts that are cancelled by the Court and in general, the penalty sanction imposed by BCSC does not provide a deterrent effect to the business actors. Besides, it is still possible to do judicial review (PK), thus extending the settlement of the case. While the obstacles to the success of law enforcement against violations of the Monopoly and Business Competition Law through the Business Competition Supervisory Commission (BCSC) are the mechanism of legal action in the form of objection to the court in the first level (district court), and in fact, several BCSC's verdicts are annulled and cancelled by the court. BCSC, which is authorized by law to examine and determine cases of violations of the Monopoly and Unfair Business Competition Law, with the district court should be equal as an authorized institution to examine and decide cases at the first level. Another obstacle and the weakness is that BCSC does not have a bailiff, in handling the case can not impose confiscation (Conservatoir Beslag), so that in the execution of the forced verdict (execution) also must be submitted the petition to the court. the legal efforts of the business actor should not be objected to the District Court, but to the High Court as well as the appeal submission in the case in general.

\section{ACKNOWLEDGMENT}

Since the enactment of Law Number 5 Year 1999 concerning Prohibition of Monopolistic Practices and Unfair Business Competition or known as LPM Law, there have been many cases of violations committed by business actors examined and terminated by the Business Competition Supervisory Commission (BCSC) as an institution established based on the law to carry out law enforcement in the field of violation of LPM Law. However, there are some weaknesses in Law Enforcement Against Violations of the Law on Prohibition of Monopolistic Practices and Unfair Business Competition. Those weaknesses are some BCSC's verdicts cancelled by the Court through the objection effort. Several cases have been handled by the Business Competition Supervisory Commission and have been terminated by the imposition of a fine, but unfortunately cancelled by the Court, as in the case of Carrefour, cooking oil cartel, the E-KTP tender case, and the other cases.
This study focused on the effectiveness of Law Enforcement Against Violations of the Law on Prohibition of Monopolistic Practices and Unfair Business Competition. On this occasion, I thank to all of those who have assisted in this study. Particularly, I thank to the Committee of ICILS 2018, the Faculty of Law of UNNES who has facilitated the presentation of this topic in the seminar. There are some weaknesses of this study, so input through discussions and seminars for this study is needed. Hopefully the results of this study can be useful in the development of science, especially legal science in the field of business.

\section{REFERENCES}

[1] Ahmad Yani \& Gunawan Wijaya, Seri Hukum Bisnis, Anti Monopoli, PT Raja Grafindo Persada, Jakarta 1999

[2] Ade Maman Suherman, Hukum Perdagangan Internasional, Lembaga Penyelesaian Sengketa WTO dan Negara Berkembang, Sinar Grafika, Jakarta 2014,

[3] Budi L. Kagramanto, Implementasi UU Number 5 Tahun 1999 Oleh BCSC, Jurnal Ilmu Hukum Yustisia, Vol, No, 2007

[4] Fukuoka, Yuki. Politics, Business and the State in PostSoeharto Indonesia, Contemporary Southeast Asia; Singapore Vol. 34, Iss. 1, (Apr 2012): 80-100.

[5] Insan Budi Maulana, Pelangi HaKI dan Anti Monopoli, Pusat Studi Hukum (PSH) Fakultas Hukum UII, Yogyakarta, 2000

[6] Jimly Asshidiqie dalam Andi Fami Lubis, dkk, 2009, Hukum Persaingan Usaha: Antara Teks dan Konteks, Komisi Pengawas Persaingan Usaha, Jakarta

[7] KPPU 2013, Media Berkala Komisi Pengawas Persaingan Usaha "KOMPETISI", edisi number 32 Tahun 2012

[8] KPPU 2016, Tahun Berburu Kartel, Laporan Tahunan Komisi Pengawas Persaingan Usaha (KPPU) 2016, Jakarta 2016

[9] Munir Fuady, Hukum Anti Monopoli, Menyongsong Era Persaingan Sehat, PT. Citra Aditya Bakti, Bandung 2003

[10] Rai Mantili, Hazar Kusmayanti, Anita Afriana, Problematika Penegakan Hukum Persaingan Usaha Di Indonesia Dalam Rangka Menciptakan Kepastian Hukum, Padjadjaran Jurnal Ilmu Hukum, Vol. 3 Number 1 Tahun 2016, pp. $116-132$

[11] Republik Indonesia 1999, Undang-Undang nomor 5 Tahun 1999 Tentang Larangan Praktek Monopoli dan Persaingan Usaha Tidak Sehat, Lembaran Negara RI Tahun 1999 No. 33, Sekretariat Negara, Jakarta.

[12] Shidarta, Hukum Perlindungan Konsumen Indonesia, PT Grasindo, jakarta 2000

[13] Satjipto Rahardjo, Masalah Penegakan Hukum, Bandung: Sinar Baru, 1983

[14] Yulianto Syahyu, Hukum Anti Dumping Indonesia, Analisis dan Panduan Praktis, Ghalia Indonesia, Jakarta 2004

[15] Yuhelson Yuhelson, The Role of Criminal Law Politics against Ambush Marketing Behavior in the Implementation of ASEAN Community, European Research Studies Journal, Volume XX, Issue 3A, 2017, pp. 673-690

[16] Zulkarnain ., Abrar Saleng, S.M. Noor, A.M.Yunus Wahid, The Role of the Management of Oil and Gas in Indonesian Borders, Journal of law , Policy and Globalization,ISTEInternational Knowledge Sharing Platform, vol-72, 2018, pp. 111 $-117$ 